\title{
Generasi Millenial dan Resep Kuliner Tradisional sebagai Budaya Bangsa Indonesia
}

\author{
Setya Putri Erdiana \\ Program Studi Magister Desain \\ Institut Teknologi Bandung
}

\begin{abstract}
Indonesia is one of the most cultured countries in the world and one of them is traditional culinary. On the other hand, Indonesian traditional culinary is now being displaced and replaced by fast food or culinary from other countries. And lately, traditional culinary is hard to find especially in big cities, it shows that interest of it decreases and only few who can cook the traditional culinary. This is the effect of the generation itself because each generation influences society. Now, millennial generation is the most influential generation, because most of them are in the productive age of 19-35 years old. Aside from being the next generation, millennial generation is also considered to be the generation that has the most influence on the emerging trends in society. Especially the use of gadgets and technology nowadays, causing them to be called instant generation, which is the opposite to people's perceptions of traditional culinary that is complicated to make and requires a long cooking time. By using qualitative research methods, it is expected to obtain data as accurately as possible with the facts and conditions. By observing and interviewing the target audience to gather information about the community's perspective on Indonesian culinary and the cooking process, also gathering theories to support the research process. Thus, the results of this study are expected to provide concept of culinary recipes traditional form of design that can be used in designing traditional recipe application that attracts millennials to cook traditional Indonesian culinary.
\end{abstract}

Key words: millenial generation, recipe, traditional Indonesian culinary

\section{PENDAHULUAN}

Indonesia merupakan negara kepulauan yang terdiri lebih dari 13.000 pulau yang memiliki beragam kebudayaan di tiap daerahnya. Berdasarkan survey yang dilakukan oleh Departemen dalam Negeri dan Badan Pusat Statistik (BPS), Indonesia memiliki 98 kota dan 410 kabupaten, dimana masing-masing daerah tersebut memiliki budaya tersendiri. Angka tersebut dapat menggambarkan kekayaan budaya yang dimiliki Indonesia, bahkan hal tersebut juga membuat Indonesia menjadi salah satu Negara dengan kebudayaan terbanyak di dunia. Dan yang menjadi salah satu kebudayaan yang dimiliki Indonesia adalah kuliner tradisional. Dengan perbedaan ciri khas kuliner di tiap daerah, seperti di Jawa Tengah yang dikenal dengan rasa manisnya dan Padang dengan bumbu rempah dan rasa pedasnya, kuliner tradisional menjadi salah satu kebudayaan yang wajib untuk dilestarikan khususnya kepada generasi muda sebagai generasi penerus bangsa. Seperti yang dikatakan oleh William wongso, pakar kuliner senior di Indonesia, bahwa sudah seharusnya generasi muda mempelajari dan menekuni kekayaan kuliner Indonesia karena kuliner Indonesia merupakan salah satu warisan budaya yang cara pembuatannya harus dilestarikan. Seorang chef yang bernama Bottura, seorang chef bintang 3 
Michelin, yang mengatakan bahwa kuliner Indonesia sesungguhnya yang memiliki rasa fantastis dan unik serta memiliki proses yang cenderung tidak terlalu rumit, dan mampu mendunia seperti kuliner Jepang atau Cina.

Kuliner tradisional yang ada saat ini cenderung tergeser keberadaannya dengan fast food ataupun kuliner yang berasal dari negara lain. Pada saat ini, kuliner tradisional seperti kue cucur, klepon, rujak, dan es cendol lebih jarang ditemui khususnya di perkotaan, dibandingkan kuliner yang berasal dari negara lain seperti pizza, spaghetti, sushi dan lainnya. Jarang ditemukannya kuliner tradisional tersebut menunjukkan minat masyarakat yang menururun akan kulinerkuliner tradisional. Padahal, seorang chef yang bernama Bottura, seorang chef bintang 3 Michelin, mengatakan bahwa kuliner Indonesia sesungguhnya yang memiliki rasa fantastis dan unik serta memiliki proses yang cenderung tidak terlalu rumit, dan mampu mendunia seperti kuliner Jepang atau Cina. Hal tersebut membuktikan bahwa sesungguhnya kuliner Indonesia memiliki rasa dan kualitas yang sama atau bahkan lebih baik dibandingkan dengan kuliner dari negara lain.

Kemunculan tiap generasi selalu mempengaruhi masyarakat secara keseluruhan. Pada saat ini, generasi milenial merupakan generasi yang banyak berperan, karena berada pada usia produktif yakni 1935 tahun. Selain sebagai generasi penerus, generasi milenial juga dianggap sebagai generasi yang paling berpengaruh terhadap tren-tren yang muncul pada masyarakat, terutama mengenai tren kuliner. Kebiasaan mereka dianggap dapat merubah pola pikir masyarakat secara umum mengenai kuliner.
Seperti yang dikatakan oleh Eve Turow, penulis buku A taste of Generation Yum: How the Millenial Generation's Love for Organic Fare, Celebrity Chefs, and Microbrews Will Make or Break the Future of Food with the Atlantic, bahwa generasi milenial menginginkan sesuatu yang nyata, yang dapat mereka lihat, rasakan, cium, dan rasakan. Sejalan dengan hal tersebut, Farah Quinn, selebriti chef Indonesia juga mengatakan bahwa generasi saat ini selalu melihat secara visual terlebih dahulu, semakin menarik tampilan makanan, maka akan semakin banyak masyarakat yang juga suka. Oleh karena itu jika ingin menguatkan kuliner Indonesia kepada generasi berikutnya hal yang dapat dilakukan adalah dengan meningkatkan kualitas tampilan suatu makanan dan meningkatkan kualitas bahan makanan. Dengan meningkatkan kedua sisi tersebut, mereka bisa menikmati hidangan kuliner Indonesia yang bergizi tinggi dan juga enak dilihat.

Berdasarkan hal tersebut maka diperlukan adanya penelitian mengenai ragam kuliner tradisional apa saja yang digemari oleh generasi milenial, serta tampilan visual kuliner seperti apa yang dapat menarik perhatian agar generasi milenial mau untuk mencoba mempraktekkan resep kuliner tradisional.

\section{METODE PENELITIAN}

Metode penelitian yang digunakan adalah pendekatan deskriptif-kualitatif. Metode ini dilakukan dengan cara mengumpulkan berbagai teori terkait dan membandingkannya untuk mendapatkan berbagai hal yang berkaitan dengan kebudayaan dan resep kuliner tradisional saat 
ini, generasi millennial dan perkembangannya. Sedangkan data-data yang berkaitan diperoleh dengan cara:

a. Kajian Pustaka

Meliputi panduan yang berkaitan dengan teori pendukung yang dilakukan dengan mengumpulkan bahan-bahan terkait yang dapat menunjang proses penelitian.

b. Pengamatan dan Observasi

Melakukan proses pengamatan secara langsung pada aplikasi resep sejenis, meliputi konsep aplikasi, navigasi, dan konsep visual seperti warna, layout, tipografi dan teknik videografi.

c. Kuisioner

Untuk mengetahui sejauh mana pengetahuan generasi millennial di Pulau Jawa terhadap kuliner tradisional Indonesia dan media apa yang paling sering digunakan.

d. Data dari internet, sebagai sumber informasi pendukung baik mengenai fenomena dan permasalahan yang ada, maupun sebagai referensi mengenai komparator kompetitor. Berupa artikel, berita, referensi, atau materi pendukung tinjauan pustaka.

Dalam penelitian ini, target audiens yang dituju memiliki kriteria sebagai berikut:

\section{Segmentasi Geografis}

Target audiens perancangan aplikasi resep kuliner tradisional Indonesia ini adalah generasi milenial yang tinggal di perkotaan besar, khususnya di Pulau Jawa.

\section{Segmentasi Demografis}

Usia: 19-35 tahun
Jenis kelamin: Laki- laki dan perempuan

Pendidikan: Sarjana atau sederajat

\section{Segmentasi Psikografis}

Target penelitian ini yakni para dewasa muda yang aktif, gemar menggunakan sosial media, suka mencoba hal-hal baru, menggunakan smartphone, memiliki hobi memasak, dan memiliki ketertarikan terhadap kuliner tradisional Indonesia.

\section{DISKUSI}

Sampel responden yang dapat mewakili kriteria populasi di atas adalah kaum dewasa muda yang berdomisilli di Pulau Jawa dengan yang berstatus mahasiswa serta pekerja atau wiraswasta, dan rentang usia 19-35 tahun. Sebanyak 50 lembar kuisioner akan disebarkan untuk mendapatkan karakteristik target audiens yang tepat. Berikut beberapa hasil kuisioner yang telah didapatkan:

Tabel 1 Diagram minat generasi millenial dalam mengonsumsi kuliner tradisional Indonesia ${ }^{a}$

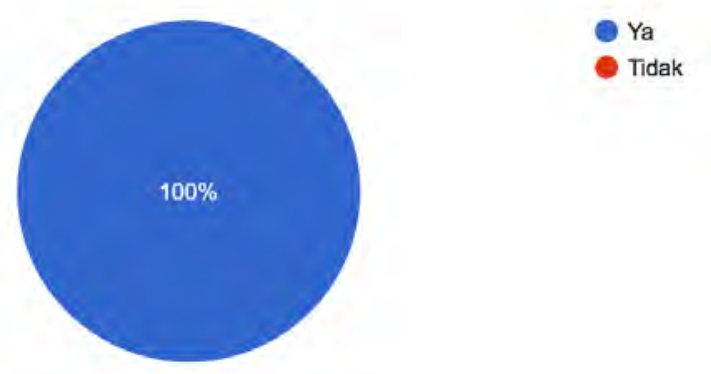

${ }^{a}$ Survey terhadap 50 responden generasi millenial berusia 18-35 tahun yang berdomisili di Pulau Jawa

Dari tabel diatas dapat terlihat bahwa $100 \%$ dari responden masih tertarik untuk mengonsumsi kuliner tradisional Indonesia dalam kesehariannya. Hal tersebut mengindikasikan bahwa sesungguhnya kuliner tradisional Indonesia masih digemari 
dan mendampatkan tempat tersendiri di hati masyarakat khususnya generasi millenial.

Tabel 2 Diagram para generasi millenial dalam memperoleh atau mendapatkan kuliner tradisional Indonesia yang dikonsumsinya ${ }^{\mathrm{a}}$

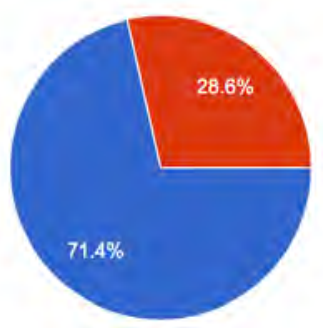

${ }^{\text {a }}$ Survey terhadap 50 responden generasi millenial berusia 18-35 tahun yang berdomisili di Pulau Jawa

Dari tabel di atas dapat terlihat bahwa $71,4 \%$ responden memilih untuk membeli kuliner tradisional dan hanya $28,4 \%$ nya yang memilih untuk memasaknya sendiri. Hal tersebut mengindikasikan bahwa generasi millenial cenderung lebih menyukai hal yang instan dan praktis sehingga mereka memilih untuk membeli kuliner tradisional tanpa mengetahui proses pembuatannya.

Tabel 3 Diagram minat generasi millenial akan kegiatan memasak ${ }^{a}$

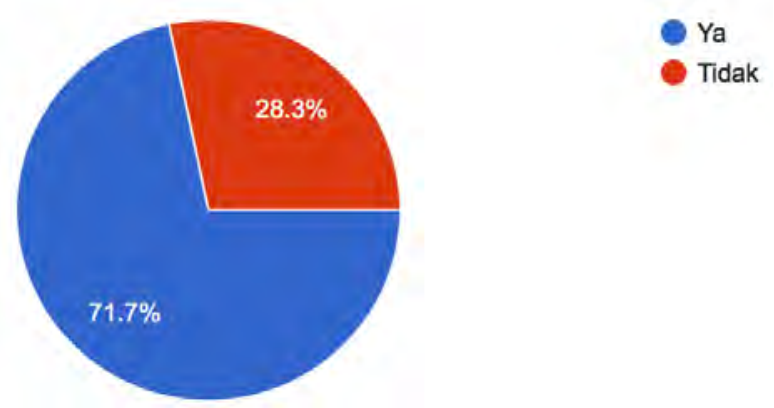

a Survey terhadap 50 responden generasi millenial berusia 18-35 tahun yang berdomisili di Pulau Jawa

Dari tabel di atas dapat terlihat bahwa $71,7 \%$ responden gemar dan terbiasa untuk memasak makanannya sendiri dan hanya $28,4 \%$ nya yang tidak suka memasak. Hal tersebut mengindikasikan bahwa generasi millenial sebenarnya peduli akan proses pembuatan makanan yang dikonsumsinya.

Tabel 4 Diagram minat generasi millenial akan jenis panganan yang dibuat ${ }^{\mathrm{a}}$

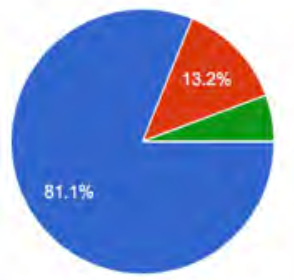

- Makanan Berat (Nasi, Mie, dan Lauk Pauk) - Roti dan kue-kue - Minuman

- Makanan Ringan (camilan dan keripik)

a Survey terhadap 50 responden generasi millenial berusia 18-35 tahun yang berdomisili di Pulau Jawa

Dari tabel di atas dapat terlihat bahwa $81,1 \%$ responden memilih untuk memasak panganan yakni berupa makanan berat atau lauk pauk, dan sebanyak 13,2\% memilih untuk memasak roti dan kue, sedangkan sisanya memilih untuk memasak camilan. Pilihan tersebut mengindikasikan bahwa generasi millenial memasak untuk keperluan makan sehari-hari yakni makanan berat atau lauk-pauk.

Tabel 5 Diagram aktivitas generasi millenial dalam memasak kuliner tradisional Indonesia tiap minggunya $^{\mathrm{a}}$
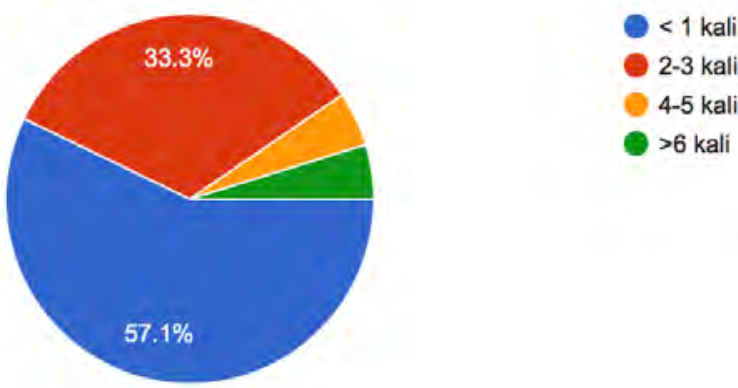

a Survey terhadap 50 responden generasi millenial berusia 18-35 tahun yang berdomisili di Pulau Jawa 
Dari tabel di atas dapat terlihat bahwa $57,1 \%$ responden memasak kuliner tradisional <1 kali, dan 33,3 \% memasak kuliner tradisional sebanyak 2-3 kali, dan sisanya sebanyak 4-5 kali serta $>6$ kali. Hal tersebut mengindikasikan bahwa generasi millenial masih sangat jarang dalam memasak kuliner tradisional Indoneisa walaupun sesungguhnya mereka sering dan gemar memasak kuliner lainnya.

Tabel 6 Diagram aktivitas generasi millenial dalam durasi waktu membaca dan mencari resep sebelum memutuskan untuk memasak ${ }^{\mathrm{a}}$

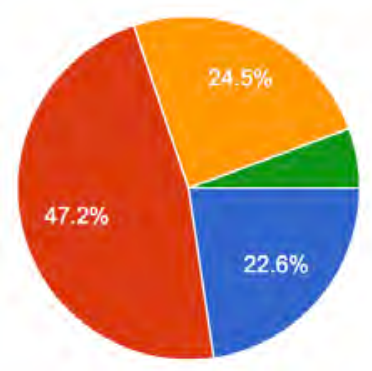

$<5$ menit

6-15 menit

16-25 menit

$>26$ menit

${ }^{\text {a }}$ Survey terhadap 50 responden generasi millenial berusia 18-35 tahun yang berdomisili di Pulau Jawa

Dari tabel di atas dapat terlihat bahwa $47,2 \%$ responden memerlukan waktu 6-15 menit dalam membaca ssebuah resep, $24,5 \%$ memerlukan waktu 16-25 menit, 22,6\% memerlukan waktu $<5$ menit dan sisanya memerlukan waktu $>26$ menit untuk mencari dan membaca resep sebelum memutuskan untuk memasak. Hal tersebut menunjukkan bahwa generasi millenial hanya memerlukan waktu yang cukup singkat dalam mencari sekaligus membaca resep. Hal ini dapat menjadi acuan bagaimana sebuah resep kuliner tradisional Indonesia akan ditampilkan.
Tabel 7 Media yang paling sering digunakan generasi millenial dalam mencari resep yang akan dipraktekkan $^{\mathrm{a}}$

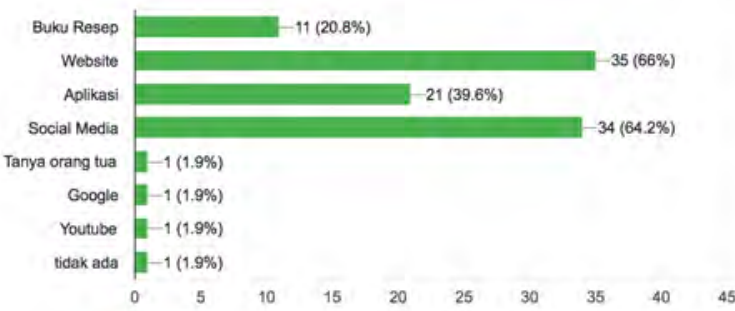

${ }^{\text {a }}$ Survey terhadap 50 responden generasi millenial berusia 18-35 tahun yang berdomisili di Pulau Jawa

Dari tabel di atas dapat terlihat bahwa $66,6 \%$ responden memilih untuk menggunakan website, $64,2 \%$ memilih menggunakan media sosial, $39,6 \%$ memilih menggunakan aplikasi, 20,8\% memilih menggunakan buku resep, dan sisanya sebanyak 3,6\% memilih lainnya. Dari angka tersebut dapat disimpulkan bahwa generasi millenial lebih memilih untuk menggunakan media digital dalam mencari sebuah informasi khususnya resep kuliner, yakni berupa website, sosial media dan juga aplikasi.

Tabel 8 Diagram yang mendorong generasi millenial untuk mempraktekkan sebuah resep ${ }^{a}$

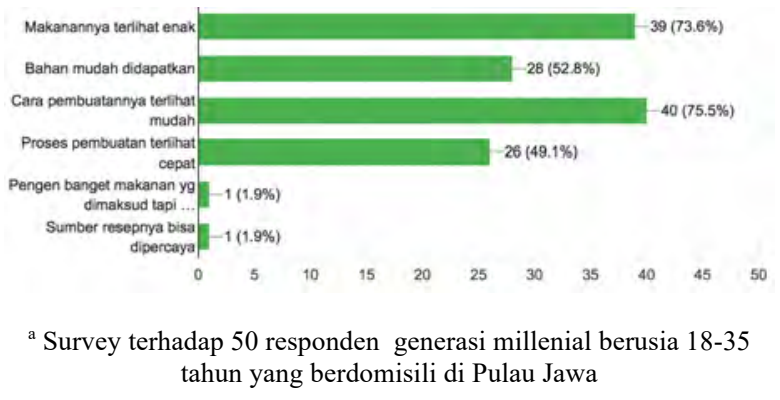

Dari tabel di atas dapat terlihat bahwa mayoritas responden tertarik mempraktekkan 
sebuah resep ketika cara pembuatannya terlihat mudah, tampilan visual makanannya terlihat enak, bahan-bahan yang digunakan mudah untuk didapatkan, dan juga proses pembuatannya yang cepat. Hal tersebut menunjukkan bahwa kepraktisan merupakan hal yang utama, dan juga tampilan visual merupak hal yang cukup penting agar mereka tertarik mempraktekkan sebuah resep.

\section{STUDI KOMPARASI APLIKASI RESEP DENGAN TARGET AUDIENS GENERASI MILLENIAL}

\section{Cookpad}

Cookpad didirikan pada tahun 1997 di Jepang dan saat ini telah memiliki lebih dari 2.8 juta resep yang beroperasi di lebih dari 60 negara dengan jumlah lebih dari 90 juta pengguna. Aplikasi resep Cookpad Indonesia sendiri juga mendapat penghargaan sebagai Aplikasi Harian Terbaik 2017 Google Play dimana termasuk ke dalam kategori aplikasi yang membantu masyarakat melakukan kegiatan sehari-hari menjadi lebih efisien dan menyenangkan. Dan juga, resep yang dibagikan telah dilihat lebih dari 1,4 milyar kali oleh pengguna Cookpad sepanjang tahun 2017 serta mendapatkan nilai 5 dari penggunanya.

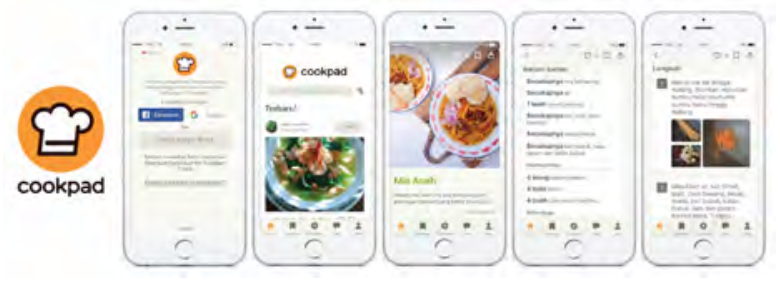

Gambar 1 Logo, fitur, dan user interface aplikasi Cookpad (dokumentasi pribadi)

Aplikasi ini menampilkan resep-resep dalam bentuk tulisan dan juga disertai dengan foto makanan. Resep yang ditampilkan dikategorikan berdasar jenis makanan serta asalnya. Misal pada makanan Indonesia yang dikategorikan berdasarkan daerah asalnya, Sumatera, Jawa Timur, Jawa Barat, Sulawesi, Bali dan sebagainya. Selain itu, pengguna dapat membagi resep pribadinya di aplikasi ini, sehingga semakin banyak orang yang mempraktekkan resep tersebut, maka semakin tinggi pula bintang yang didapatkan pengguna tersebut. Sehingga dapat dikatakan bahwa aplikasi ini memiliki sistem layaknya sosial media khusus resep.

\section{Tasty}

Aplikasi resep Tasty berawal dari video memasak rilisan Buzzfeed yang viral di media sosial. Video bergaya above point of view pertama Tasty dirilis pertama kali bulan Juli 2015, dan saat ini telah terkumpul hampir lebih dari 100 juta follower di Facebook, Instagram, dan Twitter, dimana rata-rata telah ditonton sebanyak 2,3 miliar kali setiap bulannya. Dan pada tahun 2017, Buzzfeed merilis aplikasi Tasty yang mengumpulkan semua video Tasty tersebut. Dengan menggunakan video di setiap step-by-step nya dan memiliki durasi yang relatif singkat sekitar 1-2 menit, memudahkan penggunanya untuk mengikuti resep yang ditampilkan sehingga mendapatkan nilai 4,9 dari penggunanya.

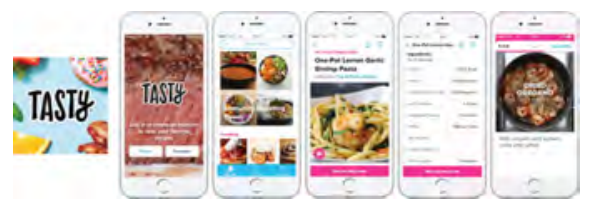

Gambar 2 Logo, fitur, dan user interface aplikasi Tasty (dokumentasi pribadi) 
Aplikasi resep ini menampilkan resep dengan petunjuk yang sangat jelas dan juga terdapat video langkah-langkah proses pembuatan, mulai dari persiapan bahan, alat hingga proses memasak, yang sangat membantu pengguna dalam mempraktekkan sebuah resep masakan. Durasi video yang ditampilkan pun sangat singkat, hanya berkisar antara 60-90 dimana hal tersebut sangat sesuai dengan karakter target audiens yakni generasi millenial yang serba instan dan lebih susah untuk fokus dalam jangka waktu yang lama.

\section{KESIMPULAN}

Generasi millenial yang pada saat ini berada pada usia produktif yakni 19-35 tahun sesungguhnya sangat tertarik akan kuliner tradisional Indonesia dan peduli terhadap bahan, proses serta asal muasal makanan yang mereka konsumsi. Hal tersebut terlihat dari hasil penelitian diatas bahwa seluruh generasi millenial masih mengonsumsi kuliner tradisional dan mereka lebih memilih untuk memasak makanan yang dikonsumsinya sendiri. Namun disisi lain, jarang sekali yang memasak kuliner tradisional Indonesia, dimana mereka lebih memilih untuk membelinya dikarenakan persepsi para generasi millenial akan kuliner tradisional yang susah untuk dibuat dan memerlukan proses memasak yang lama.

Resep kuliner tradisional sesungguhnya justru lebih mudah dipraktekkan dan dibuat karena bahan-bahan yang telah tersedia disekitar. Bahkan jika dibandingkan dengan resep-resep kuliner dari mancanegara, resep dari barat lah yang lebih susah untuk dipraktekkan dikarenakan bahan-bahannya yang terkadang sangat susah ditemukan di keseharian. Namun dengan adanya resepresep mancanegara yang ditampilkan dengan tampilan yang menarik, jelas dan padat serta ditambahkan dengan video proses pembuatan, hal inilah yang membuat resepresep kuliner mancanegara terlihat lebih mudah untuk dipraktekkan. Dan juga penggunaan media yang serba digital saat ini yang sangat akrab dengan generasi millenial saat ini, lebih memudahkan mereka dalam mengakses informasi yang diperlukan.

Maka dari itu, dengan adanya penelitian ini mengenai generasi millenial dan resep kuliner tradisional Indonesia sebagai salah satu budaya Indonesia, diharapkan dapat dijadikan langkah awal dalam penelitian berikutnya maupun dijadikan acuan dan landasan dalam sebuah perancangan pada suatu media yang sesusai dengan generasi millenial saat ini, yang berisikan resep kuliner tradisional Indonesia untuk melestarikan salah satu kebudayaan Indonesia sebagai generasi penerus bangsa.

\section{DAFTAR PUSTAKA}

[1] Apa itu IOS, sejarah dan berbagai versinya?, data diperoleh melalui situs internet https://dailysocial.id/post/apaitu-ios. Diunduh pada tanggal 1 Mei 2018

[2] Beautiful Food, Captured Beautifully by Elke Talbot, data diperoleh melalui situs internet

https://www.nikonusa.com/en/learnand-explore/a/tipsandtechniques/beautiful-food-capturedbeautifully-by-elke-talbot.html/. Diunduh pada tanggal 1 Mei 2018.

[3] Chef 3 Bintang Michelin, Massimo Bottura Yakin Masakan Indonesia Bisa Mendunia, data diperoleh melalui situs internet https://www.fimela.com/lifestyle- 
relationship/chef-3-bintang michelin massimo-bottura-yakin-masakanindonesia-bisa-mendunia-1603216.html. Diunduh pada tanggal 1 Mei 2018.

[4] Empat kelebihan IOS dibanding Android, data diperoleh melalui situs internet

https://tekno.tempo.co/read/524832/4kelebihan-ios-dibanding-android.

Diunduh pada tanggal 1 Mei 2018.

[5] Generasi Milenial sebagai Generasi Penerus Kuliner Indonesia, data diperoleh melalui situs internet https://food.detik.com/info-kuliner/d3389405/iniperan-generasi-millennialdalam-membentuk-tren-makanan-2017. Diunduh pada tanggal 1 Mei 2018.

[6] Kuliner Tradisional Indonesia, data diperoleh melalui situs internet https://id.wikipedia.org/wiki/Kuliner_tra disional_indonesia. Diunduh pada tanggal 1 Mei 2018.

[7] Mengenal Jenis-jenis Tipografi, data diperoleh melalui situs internet http://kelasdesain.com/mengenal-jenisjenis-tipografi/ Diunduh pada tanggal 3 Mei 2018

[8] Pusaka Kuliner, Warisan Budaya yang Harus Dilestarikan oleh Generasi Muda, data diperoleh melalui situs internet https://travel.kompas.com/read/2017/04/ 15/220200827/generasi.milenial.sebagai.g enerasi.penerus.kuliner.indonesia.

Diunduh pada tanggal 1 Mei 2018. Diakses 28 Agustus 2018. 